\title{
Donors' Responses to Arab Uprisings: Old Medicine in New Bottles?
}

\author{
Yousry Mustapha
}

\begin{abstract}
This article examines Western donors' reactions to the Arab uprisings and whether there has been a radical departure, since January 2011, from previous modes of engagement. It takes the EU and USA as case studies of the failure of aid policies to promote democracy prior to the uprisings, and questions whether a new approach has been adopted after the demise of Mubarak in Egypt. It argues that for the EU, positive conditionality is seen as a central element in reforming funding policies while for the USA, there seems to be no significant change in the funding policy. The highly restrictive political and cultural context affecting international agency has not changed after the ousting of the former regime, nor have the underlying factors influencing the direction of foreign funding in the region changed. In short, what this article concludes is that we are far from witnessing a paradigm shift.
\end{abstract}

\begin{abstract}
1 Background
This article examines the extent to which donor policies have been influenced by the political developments in the region. It relies on the analysis of policy statements and strategy papers of key donors, informal interviews with a select number of bilateral and multilateral donors, as well as a series of interviews with recipients of foreign aid. The article seeks to identify what the donors' initial response to the uprisings was, the nature of their engagements with the new political configurations of power and its implications for supporting positive social and political change, in particular on the democratisation front, which has been a key priority for all donors.
\end{abstract}

According OECD's Recipient Aid Charts for the years 2007-09, ${ }^{1}$ the main sources of funding for Egypt are first, the USA, followed by Germany, the EU, France, Japan and then Arab countries. Tunisian funding sources are different: France is first, followed by the EU, Japan, Spain, Italy, and Arab countries contributing less. However, there are other funders, governmental and nongovernmental, who are funding initiatives with various goals, which are both formal and informal in nature. In addition, the intergovernmental agencies have been active during past years in providing support and technical assistance on a wide array of issues related to development, democracy and governance, and human rights. According to an unpublished survey conducted by the Arab Fund for Human Rights, there are more than 100 (formal) funders working in the Arab region who provide different kinds of support in different thematic areas. Egypt is known for its abundance of international aid emanating from multiple actors, and several donors report allocation and absorption problems. In terms of volume, the biggest donor in the area of democracy, governance and human rights is the USA via USAID, followed by UNDP and the European Commission. Other important actors in this area include: the Netherlands; Sweden (SIDA, Swedish International Development Agency); the UK; Canada (CIDA, Canadian International Development Agency); Finland; the World Bank; NED (National Endowment for Democracy); NDI (National Democratic Institute); IRI (International Republican Institute); the Ford Foundation; Freedom House; OSI (Open Society Institute); Oxfam; IFES (International Foundation for Electoral Systems); the German Party Foundations FES (Friedrich Ebert Foundation), KAS (Konrad Adenauer Foundation) and FNS (Friedrich Naumann Foundation); and many others active in related areas (Kausch 2010).

IDS Bulletin Volume 43 Number 1 January 2012 (c) 2012 The Author. IDS Bulletin @ 2012 Institute of Development Studies Published by Blackwell Publishing Ltd, 9600 Garsington Road, Oxford OX4 2DQ, UK and 350 Main Street, Malden, MA 02148, USA 
While governments have the lion's share of the external support, civil society organisations also have a share. Givil society, in this context, essentially comprises human rights organisations with their different branches, and development organisations, which include new nongovernmental organisations (NGOs), as well as old ones that have reformulated their missions and objectives and redesigned their programmes to take part in the new development realm. Although the number of NGOs has increased rapidly during the past two decades, the legal and political environments are not encouraging but restrictive: one of the most restrictive in NGO law is that relating to receiving foreign funding. In Tunisia, the situation is even more complicated than in Egypt. In Tunisia, the Ministry of Interior had been highly active in monitoring funding to civil society groups. Although the law does not explicitly require prior approval for foreign funding, some groups report that foreign funding has been monitored through the central government bank, and the government has frozen or confiscated NGO funds for no clear reason. As a result, organisations have limited ability to obtain funds with which to sustain themselves. ${ }^{2}$ The aggression against human rights activists is evident.

Although the international aid to the governments in the region started in the $1970 \mathrm{~s}$, the beginning of 1990 saw the onset of foreign aid to the new emergent civil society groups. In Egypt, the Egyptian Organization for Human Rights received its first foreign funding in 1992. It was a point of departure, as many other human rights organisations emerged after that, relying considerably on foreign support for their survival. There is no doubt that the foreign fund had played a critical role in developing and constructing civil society groups that work on human rights-related and development activities during this foundational moment.

During the 1990s, there were two factors that had a significant impact on the establishment and directions of the active non-governmental groups. First, UN world conferences and summits led to increased recognition of the role of civil society organisations, in particular in relation to specific themes such as women's rights, child rights and human development. ${ }^{3}$ The second factor was the violent confrontation between armed Islamic groups and the state, especially in Egypt and Algeria, which significantly shaped aspects of relations with the international donors as well as the agenda of human rights groups. However, paradoxically, in supporting human rights groups, many funders paid special attention to violations of civil and political rights such as emergency laws, torture, right to life, etc., while turning a blind eye to many governmental abuses in the field of human rights or the failure to achieve progress in the field of development.

At that time, democracy and political reform were not a top priority. In addition, politics, development and human rights were seen as separate domains. On the one hand, there was a controversial debate about the link between politics and civil society in general and human rights' NGOs in particular. That is, civil society organisations were seen by some as apolitical entities, while others, especially political activists, condemned this approach and described it as a sort of 'political nihilism'. On the other hand, there was a gap (institutional and conceptual) between human rights and development, which manifested in the lack of cooperation between human rights and development NGOs. Social and economic rights were also neglected by mainstream human rights groups.

Nevertheless, by the end of the 1990s, democracy and political reform gradually became an issue at both international and local levels. Likewise, a steady process to bridge the gap between human rights and development was initiated mainly by development organisations. The impact of the international community was noticeable both through its shaping of the agenda or through its funds. A number of initiatives emerged from 2000 onwards as part of a wider policy to promote democracy. For example, the European Initiative for Democracy and Human Rights (EIDHR) (2000-06), which was replaced by the European Instrument for Democracy and Human Rights (EIDHR) in 2006; and the Broader Middle East and North Africa (BMENA) Initiative of 2004, which replaced the Middle East Partnership Initiatives (MEPI) of 2002.

It is important to mention that such democracypromoting and development initiatives coincided with other political events, most notably September 11 th 2001 and the invasion of Iraq in 2003. In this context, democratic reform 
processes were tied to security concerns. Such volatile political context had a dramatic impact on international cooperation in terms of priorities and effectiveness of foreign aid. Given that security and 'stability' in the region were prioritised, national governments were given the pretext to adopt restrictive legislations and to bargain for democratic reform. In addition, since September 11 th, democratic initiatives in the Muslim-majority countries had been strongly affected by the war against terror. Accordingly, democracy was not seen only as a political issue, but cultural as well. Although it has to be achieved through political and legal reform, it should also, in Islamic countries, be a result of cultural and religious reform.

Generally speaking, despite the resistance of the local authorities and the hostile legal and political environment against civil society groups, the foreign fund for democracy became channelled to new areas of democracy promotion such as monitoring elections, political participation, media freedom and the right to association and governance. Foreign funding also supported the emergence of a new generation of NGOs, particularly in Egypt, that were more politically oriented after 2000 and involved the participation of younger generations who had benefited from a different kind of technical assistance and capacity-building activities that included training, visits and study tours.

\section{Post-uprisings debate about international aid}

Much of the writing on Western aid in the light of the Arab uprisings has tended to focus on US and EU assistance, which are both critically reviewed. For instance, there is a belief that foreign aid had no significant input on the uprisings:

Neither the EU nor the EU member states can claim that the current transition process in Tunisia or Egypt is a direct result of the European democratization policy, although for more than fifteen years, through various policy instruments and approaches (such as the Euro-Mediterranean Partnership and European Neighbourhood Policy) the EU has made a lot of efforts and has invested not only in economic cooperation, but also in democratization projects. (Schafer 2011)

The US administration was subjected to pressure from the Egyptian government not to support the activities of civil society; however, civil society organisations were also reluctant to approach US funding. Hence, it was clear that those two main contributors as well as other intergovernmental and non-governmental donors should revisit the policies which failed to achieve tangible progress. One of the main critiques was that under the guise of 'Stability' and 'Security', the EU had supported autocratic regimes. The relation with Zine El Abidine Ben Ali was a flagrant example.

European Union institutions, member states and influential southern European governments supported the Tunisian regime up until the very day, on 14 January 2011 , when Zine El Abidine Ben Ali was forced to flee the country. On the website of the Italian Foreign Ministry, for one, Tunisia is still praised for its 'political and social stability'. The assessment of the performance of the Tunisian regime was so positive that, according to EU Commissioner Štefan Füle who is in charge of the Union's flagship European Neighbourhood Policy, ENP (including Tunisia as its partner country): 'Tunisia is an important and reliable partner for the EU, with which it has forged strong relations based on shared values and mutual respect and understanding.' Accordingly, in May 2010 the EU was prepared to grant Tunisia 'advanced status', which would have ensured a more intense political dialogue and included the prospect of a deep free trade agreement. (Holm et al. 2011)

Generally, the failure of Western aid to contribute to initiatives that genuinely promote social and political change is evident at several levels. First, failure to boost democracy and improve human rights; second, failure to encourage good governance and greater transparency; third, excessive focus on governments and elites; fourth, waste and mismanagement; fifth, mixed record on boosting trade (Scarpetta and Swidlicki 2011). These manifestations show that international aid is politically driven from two sides - donors and recipients. That failure is not only a result of mismanagement of the international aid, but also due to the political context of international cooperation. Taking into consideration the lack of political will to carry out political and economic reform, the incentives are also weak. This helps to explain the European aid to Eastern Europe 
and Middle East. 'The biggest reason why the EU managed to influence the political trajectories of Romania, Serbia, Slovakia and Turkey, but failed with the North African states, is that the former were motivated by the goal of accession, the EU has not yet found a successful means of influencing neighbours that have little chance of joining the EU' (Grant 2011).

The other example of criticism is about the US support to Egypt. Although Egypt is the second largest recipient of US foreign assistance, a small part of this assistance is directed to civil society to promote democracy and governance, and this has been an area of tension between the two countries. Mubarak's regime resisted the US contribution to independent civil society groups and this affected the amount of funding directed to them. Accordingly, some experts note that only a small proportion of the USAID's democracy and governance $(D \& G)$ funds are spent on independent Egyptian groups and an even smaller proportion on groups that do not receive approval from the Egyptian government. The vast majority of USAID D\&G assistance goes to Government-of-Egypt-approved consensual, government-to-government projects (Sharp 2011). ${ }^{4}$ However, while the major US funding goes through USAID, there are other alternative channels. The Middle East Partnership Initiative (MEPI), which was established by the Bush administration in 2002, represents another funding avenue. As compared with USAID's programming, MEPI projects are smaller scale and shorter term, with more modest budgets. In this sense, MEPI is more flexible in dealing with civil society groups and addressing sensitive issues, for example MEPI stepped in to provide funding for civil society organisations not registered with the Egyptian government under its NGO law following USAID's decision in 2009 to no longer provide direct support to such groups. While MEPI was active in Egypt under Mubarak's regime, it engaged in almost no democracy and governance programming in Tunisia prior to the fall of Ben Ali, although it has one of its two regional offices in Tunis (McInerney 2011).

According to McInerney, the overall impact of USAID/Egypt's programmes in democracy and governance was unnoticeable in indexes describing the country's democratic environment (McInerney 2011: 80-90). The report explained this shortcoming as follows:
A major contributing factor to the limited achievements for some of these programs resulted from a lack of support from the Government of Egypt. According to a mission official, the Government of Egypt has resisted USAID/Egypt's democracy and governance program and has suspended the activities of many U.S. NGOs because Egyptian officials thought these organizations were too aggressive. Notwithstanding the Egyptian government's negative actions, U.S. decisionmakers did not terminate the democracy and government program. ${ }^{5}$

It is true that the lack of support of the Egyptian government is an important factor. Yet, it is not sufficient to explain the shortcomings of international support. There are other factors relating to the US policies in the region in addition to other deficits relating to the civil society domain, which includes inefficient and undemocratic groups. But generally, international agencies use 'the lack of support of local partners' to justify the shortfalls.

The disrespect of the foreign fund in general and the US fund in particular, is dominant among many pro-government political actors and those who have a nationalistic ideological mindset. The new political movements, such as the Kifaya (Enough) movement did not receive funding and they declare openly that they are against foreign funding. ${ }^{6}$ Moreover, there are civil society groups who are very reluctant to receive US governmental support. However, many new NGOs, especially those that emerged after 2000, are the main recipients of that fund, either through USAID, MEPI (Middle East Partnership Initiative), Freedom House or NDI (National Democratic Institute). The anti-US groups regard such funding as a risk that may lead to the de-legitimisation of local actors.

This was the context of supporting democracy and political reform before the revolution. Certainly there were significant differences between countries in the region depending on the political and legal environment, the nature and history of civil society and political actors, as well as the degree of political and cultural resistance to foreign aid. To address donors' responses to the Arab uprisings, this context should be taken into consideration. In terms of donors' engagement since the revolution it needs to be asked whether there any significant change in funding strategies? 


\section{Responses of donors' community}

It is apparent that both governmental and nongovernmental donors were surprised by the uprisings, as were all those concerned with political reform in the Arab region and they have tried to respond to such developments in different ways. For instance, official and informal visits to the region were common; meetings with concerned parties, including youth and representatives of civil groups were organised, rapid assessments of the situation were conducted and contingency funds were offered. In addition, certain organisations and agencies revisited their strategies trying to match the new needs. Also, the tendency of some international organisations to operate directly in the region has been noticed. Politically, it seems that there were efforts not only to understand the new developments, but to build bridges with the new political actors who may shape the future political configurations in the country, namely the Islamist political actors and youth coalitions. But for non-governmental donors, it seems that the question was: how can they approach the new 'unidentified' activists?

Although all are claiming or seeking new approaches, there are doubts regarding the ability of the international donors to engage effectively in post-revolution contexts. There are question marks regarding their willingness to change their own funding approach; whether their approach is able to capture what is happening on the ground and whether donor collaboration is prioritised.

\subsection{Governmental donors}

Neither the USA nor the EU reacted promptly to the Arab uprisings. As mentioned by some commentators:

... when protests began in Tahrir Square in January, the EU was slow and hesitant to react. Its first official response, drafted by High Representative Catherine Ashton, seemed outdated the moment it was released to the world's media. Europe's position was defined by a subsequent joint statement issued by British Prime Minster David Cameron, German Chancellor Angela Merkel and French President Nicolas Sarkozy, who made it clear that Mubarak could not count on European Support. (Dworkin et al. 2011)

In February 2011, after Catherine Ashton visited Tunisia and Egypt, she highlighted the challenges facing the transition period rather than the EU's strategy of engagement. In an official statement, she said:

During my visits I had meetings with the transitional governments, as well as opposition groups, civil society and the young. These meetings have confirmed that we face a threefold challenge and need to put together a threefold response:

- We need to help build what I call deep democracy (political reform, elections, institution building, fight against corruption, independent judiciary and support to civil society). Where relevant, we can draw on our own history of building democracy and reconciliation including from those among us who have gone through these transitions recently.

- We also need to work on economic development. We are dealing with extremely young populations, with high unemployment; a lack of opportunities and significant social imbalances...

- Third we have to consider what we can do to facilitate people to people contacts, exchanges and mobility while avoiding uncontrolled migration flows.

(Ashton 2011)

Such political language is ambiguous. For example, Ashton used the term 'deep democracy' to describe the same elements of the traditional approach to promote democracy and human rights that focused on procedural dimensions of democracy. However, there is no clarification about the difference between democracy and 'deep democracy'. In another instance, Ashton used the term 'sustainable stability' without clarification about the difference between this sustainable one and the traditional concept of stability. It seems there is no shift in prioritising security and stability (or in other words combating 'terrorism' and 'illegal' migration) and the Arab-Israeli conflict over endorsing indigenous social and political forces. Therefore, Ashton is trying to use new terminology to describe the same position.

In general, two main slogans frame the EU postArab uprisings policy: these are the ' $3 \mathrm{Ms}$ : Money, Market and Mobility' and 'More for More'. Regarding the first, Catherine Ashton stated that the EU plans to support its Southern 
neighbours through money: meaning resources for transitions to democracy and economic support, for example to help substitute for the loss of tourism in Egypt and Tunisia. Market access refers to trade opportunities with the EU and mobility means the ability of business men and business women to move around, in order to conduct business more effectively. ${ }^{7}$

On the other hand, 'More for More' reflects the longstanding debate about conditionality of aid. This approach represents 'one of the pillars of the new Neighbourhood Policy, and is based on positive conditionality: if partner countries introduce more reforms then they will receive more benefits (more funds and more integration). This includes demands to set benchmarks to measure progress'. ${ }^{8}$ This approach was drafted clearly in the Joint Communication of the European Commission which, following the uprisings, presented a new approach entitled: 'A Partnership for Democracy and Shared Prosperity with the Southern Mediterranean'. According to the official document, this new approach 'represents a fundamental step in the EU's relationship with those partners that commit themselves to specific, measurable reforms. It is an incentive-based approach based on more differentiation ("more for more")'. Some benchmarks were set. In this context:

... free and fair elections should be the entry qualification for the Partnership. It also means closer cooperation in the context of the Common Foreign and Security Policy (CFSP) and more joint work in international fora on issues of common interest. The EU will continue to offer its commitment and support to the peaceful resolution of disputes within and between States in the region. The Partnership should be underpinned by enhanced political dialogue. The EU will step up bilateral political dialogue at all levels, as soon as local conditions allow, with a strong focus on human rights and political accountability. ${ }^{9}$

'More for More' is a policy intended to redress previous failures in promoting democracy in the South Mediterranean. Nevertheless, it is not clear how the EU, through its aid, can make its partners in the South accountable. Likewise, it is not clear if the EU countries themselves are willing to hold these governments accountable or if there is room to compromise in favour of 'stability' and 'security'. And if so, EU and European governments will be accountable to whom? In this regard, it is useful to recall what was mentioned by EU Enlargement and Neighbourhood Policy Commissioner, Štefan Füle, to the European Parliament's Committee on Foreign Affairs in February 2011. He said, 'Many of us fell prey to the assumption that authoritarian regimes were a guarantee of stability in the region. This was not even Realpolitik. It was, at best, short-termism - and the kind of short-termism that makes the long term ever more difficult to build' ${ }^{10}$

As for US support, there were some immediate reactions from the US side. After revolutions it was expected that USAID will clearly play a leading role in supporting Egypt's transition immediately following Secretary Clinton's announcement that $\$ 150$ million in unspent funds were being reprogrammed to support Egypt's transition, USAID released a pair of Annual Program Statements (APS) for new grants to be given. The first statement is for an expected 50 grants with a total value of up to $\$ 65$ million for democracy and governance programming, with five main areas of focus: Civic Engagement/Civic Awareness; Elections and Political Processes; Access to Justice/Human Rights; Transparency and Accountability; and Civic Participation. The second APS is for an expected 60 grants worth a total of approximately $\$ 100$ million to provide economic support to Egypt (along with the $\$ 150$ million reprogrammed) the funding for democracy and governance also includes $\$ 15$ million in unspent funds that were originally designated for that purpose (McInerney 2011: 80-90).

While the USA has earmarked substantial funding, the strategic direction of engaging with the new political context remains unclear. Donors including the USA assumed that the new legal and political environment in Egypt would facilitate the implementation of bilateral agreements which were constrained under the previous regime, but there are indicators that there is no significant change. The Egyptian Minister of International Cooperation, Fayza Aboul Naga, attacked the international support to civil society: 'I am not sure at this stage [if] we still need somebody to tell us what is or is not good for us - or worse, to force it on us', she told the Wall Street Journal (Trofimov 2011). 
Therefore, the US support to civil society groups, especially the unregistered groups, resumes the pre-uprisings controversy about foreign funding. Recently, the ruling Supreme Council of the Armed Forces (SCAF) has steadily escalated a campaign against civil society groups. On 12 July 2011, Fayza Aboul Naga announced that the government would establish a commission of inquiry to investigate the funding of civil society organisations. Only two weeks later, state-owned October Magazine ran a cover story - illustrated with a crude depiction of US Ambassador to Egypt Anne Patterson burning Tahrir Square with flaming US dollars - that accused the USA of undermining Egypt's revolution by funding civil society organisations. ${ }^{11}$

Such a situation has had a negative impact on receiving funding by civil society groups, not only from the USA, but also from other sources in Egypt. Although the Tunisian authorities were more aggressive in dealing with foreign funding to civil society after the uprisings, the situation in Tunisia is better than Egypt. Finally, the political instability has affected all the bilateral agreements. Many agreements are held up as the governments are transitional.

\subsection{UN agencies}

It is difficult to see concrete immediate responses by the UN agencies. This is understandable as UN agencies mainly approach governments and after the uprisings, there was political flux. In addition, UN agencies are bureaucratic in terms of decision-making, which disallows them to make quick responses. In this context, it was noticed that their responses were limited to actions such as official statements, visits to the region, conferences with stakeholders or revisiting their strategies in the region.

For example, UNDP developed a strategy to identify the key areas of support that UNDP can provide. Generally, the strategy addresses a wide variety of areas, including political and economic reform, justice and security reform, gender equality, youth inclusion, media reform, fighting against corruption, and governance. ${ }^{12}$

On 5 June 2011, UN Women's Executive Director, Michelle Bachelet, visited Egypt and delivered a speech at a seminar entitled, 'International Forum on Pathways of Democratic Transitions', organised by UNDP in Cairo. After Cairo,
Bachelet visited Tunisia. In both countries, she highlighted the critical role women have played in the movement for democracy, and the need to make gender equality and women's empowerment a cornerstone of the ongoing reform process.

Another example is the International Labour Organisation (ILO) response, which was limited to visits, meetings and official statements. ILO officials expressed their willingness to support and actively engage in the transition process. They highlighted issues under their mandate, mainly decent work, unemployment and underemployment, social security, labour market governance, the right to work, freedom of association and the right to organise. According to Nada Al Nashif, the ILO Regional Director for Arab States:

... the official statements by Director General Juan Somavia had charted a consistent and principled course of the ILO as it called on authorities to respect workers' rights and to use social dialogue as means to achieve social justice and democracy. A special meeting of Arab Tripartite leaders-workers of Tunisia, Employers of Algeria and the new Minister of Labour of Egypt, at the ILO Governing Body in March 2011 had further confirmed the ILO's commitment to this momentous transformation. The Arab Youth Panel during the International Labour Conference had cemented the direction of our response. ${ }^{13}$

The United Nations High Commissioner for Human Rights, Navi Pillay, was very clear about the difficulty to respond effectively to the new situation in the Middle East. In a press conference in Geneva on 30 June 2011, she stated that her organisation, never overresourced, was stretched to breaking point. Therefore it was not easy to carry out the extra work. To do so, she often had to move staff from the jobs they were supposed to be doing. During these extraordinary times in North Africa and the Middle East, she said, 'I have not been able to reinforce the offices dealing with this region'. ${ }^{14}$

\subsection{Non-governmental donors}

Non-governmental donors have more flexibility in responding to the new developments in the region, as their mission is to support civil society groups and facilitate communication and interaction, at least with the 'well-known' civil 
society groups. Thematically, democratic transition and civic engagement is the framework for many activities, which include activities relating to civil and political rights, as well as economic and social rights. Supporting youth activism is also high in their priorities.

Other issues have emerged by international organisations, such as transitional justice and humanitarian assistance. Yet, there is no consistent process to identify needs and priorities. Many donors have to rely on what is called 'rapid assessment', which has been the main tool of many donors and re-granting entities to identify the post-revolutions' needs. Generally, there is a tendency to address new emergent needs, but also to continue the regular human rights work with a new vision that suits the new development. No doubt rapid assessment is a good tool for quick responses, but it is unsuitable for strategic interventions. In addition, such a tool should not stop further in-depth assessment to understand the complicated situation in each country. Without revealing the underlying power dynamics, it is easy for donors to respond by falling back on the same old actors or to consider them as the main gateway to reaching out to others.

However, while it was easy for many funders to approach the well-known civil society groups, it was and still is complicated to approach the high number of the newly emergent groups, as well as to extend their support to actors outside capitals or big cities. This difficulty, to some extent, is justifiable because, for instance, a lot of new unregistered groups are emerging with different political and ideological backgrounds in a highly dynamic and changeable environment. In addition, many of these groups are active virtually without any articulate institutional set-up. Currently, the governmental attack against foreign funding in Egypt makes many donors cautious and they prefer to keep a low profile and not to take a more ambitious approach to engage with new actors.

In this context, it is convenient to highlight some responses. For instance, George Soros, Chairman of the Open Society Foundations (OSF), responded quickly. In an article published soon after the Egyptian uprising he said:

I am, as a general rule, wary of revolutions. But in the case of Egypt, I see a good chance of success. As a committed advocate of democracy and open society, I cannot help but share in the enthusiasm that is sweeping across the Middle East. I hope President Obama will expeditiously support the people of Egypt. My foundations are prepared to contribute what they can. In practice, that means establishing resource centers for supporting the rule of law, constitutional reform, fighting corruption and strengthening democratic institutions in those countries that request help in establishing them, while staying out of those countries where such efforts are not welcome. (Soros 2011)

Practically, OSF allocated an additional or contingency fund to support local actors in both Tunisia and Egypt through what is called the Arab Transition Fund. ${ }^{15}$

Operationally, the re-granting organisations may have flexibility to communicate with the local communities which facilitate delivering small grants to a wider scope of local actors. Politically, this approach could minimise the internal political and cultural resistance to the foreign fund. But, on the other hand, it might be risky as some intermediary NGOs may lose their balance because of pumping a lot of money that may outweigh their institutional capacity. In addition, it might lead to mismanagement of grants due to lack of technical experience, conflict of interests or the application of exclusionary policies in relation to the selection process of partners.

The Sigrid Rausing Trust, a grant-giving foundation based in London, has responded through what is called 'the MENA Strategic Fund'. Like the OSF's Arab Transition Fund, it is a special Trust initiative which was set up in 2011 to support grassroots human rights organisations in their response to the unprecedented opportunities and challenges created by revolution, conflict and crisis across the Middle East and North Africa. In particular, the Fund recognises the importance of supporting civil society in Egypt and Tunisia during their process of democratic transition and political reform, and the need to support groups documenting human rights violations in Libya, Bahrain, Yemen and Syria. The Trust aims through a combination of direct granting, project funding and sub-granting - to fund established and emerging organisations and human rights defenders that document human rights violations; also to advocate for freedom of assembly, association and expression; support victims of 
arbitrary arrest, detention and torture by state security forces; seek justice and redress for those killed and advocate for the rights of women, religious minorities, sexual minorities and refugees.

Another trend that could be seen after the revolutions is that many international organisations concerned with democracy and human rights began to operate directly in the region. Although organisations such as the International Foundation for Electoral Systems (IFES) and the International Center for Transitional Justice (ICTJ) had been working from the region before the uprisings, many others established their offices after January 2011, for example the International Institute for Democracy and Electoral Assistance (Idea); the ICTJ office in Cairo and the International Bar Association's Human Rights Institute (IBAHRI); the latter of which is exploring the possibility to establish an office in Cairo. These international organisations became visible after the uprisings. While such organisations tend to engage with local actors in the transition processes, it seems that they were optimistic regarding the political and legal environment that would allow them to operate without restrictions. However, the recent attack against foreign funding in Egypt, and in turn the work of the international organisation, may cast a shadow on this optimism.

Unfortunately, the lack of communication and coordination among donors may affect their grant-making strategies. For example, duplicating the same activities or funding the same grantee for the same activity can occur. Yet, there were very few joint activities by donors to assess the new development. There have been very few cases of donor coordination meetings.

\section{Conclusion}

It is important to note that there has not been a change in the cultural and political context in which Western donors are engaging with local actors - hence to act as if there is an entirely free political environment to work with is highly illusionary. However, there were questions as to whether their enthusiasm for supporting democracy and rights would be matched by a new approach to engagement.

Donors continue to release funding through the usual civil society channels, despite a pronounced policy of supporting youth. In fact the term
'Youth' which is being used excessively after the uprisings is more ideological and political than institutional. In other words, young people have been active in the streets or as virtual actors and in media discourse, but they are barely organised institutionally. Youth coalitions for example are many, some are part of the political groups and others are not clearly identified. In this context, donors have no channels through which to communicate with many of them, except through political channels or ordinary civil society groups. In addition, the majority of youth are difficult to approach because they are detached from political and civil society domains. Accordingly, effective engagement of youth will not be achieved as a short-term plan, but should be seen as a long-term strategy. Otherwise, donors will play a role in creating a new 'youth-elitism'.

Moreover, security interests continue to trump genuine support for democratisation movements. For example, combating terrorism, 'illegal' migration, and the Arab-Israeli conflict, which had framed the relation between Arab and Western countries, are still issues to be considered. It is clear that there is no clear new vision about the impact of such critical issues on international cooperation. However, the foreign policy interests continue to direct foreign donors' policies in a way that runs counter to the interests of advancing progressive social and political change. This is no more evident than in the sudden rush of many international policy actors to engage with the Muslim Brotherhood at the expense of other actors.

This indicates that the power interests that shape the geo-strategic interests of donors in the region, as well as the continued reliance on failed approaches, coupled with a highly antagonistic political environment towards Western aid has undermined the prospects of funding policies that better speak to the priorities of progressive local actors. Some channels of Western funding, which are less directly associated with geostrategic agendas, have sought to identify new actors and increase support for promoting democracy and social justice. However, they still face the challenge of overcoming the cultural and political barriers in creative ways.

It seems that while there has been a shift in funding patterns, there is as yet no evidence of a paradigm shift. 


\section{Notes}

1 www.oecd.org/countrylist/0,3349,en 2649 $20118525602317 \quad 1 \quad 1 \quad 1 \quad 1,00 . h t m l$

2 Global Trends in NGO Law 3.3, June 2011, www.icnl.org/knowledge/globaltrends/ GloTrends3-1.htm

3 It is worth mentioning that Cairo hosted one of these conferences: the International Conference on Population and Development in 1994. Ironically, Tunisia hosted the second phase of the World Summit on the Information Society (WSIS) in 2005.

4 The US aid for democracy and governance is a small part of the economic assistance, which is divided among several sectors. In the financial year 2009/10, the fund for democracy and governance was $\$ 23.5$ million and $\$ 29$ million, respectively, although the military fund is around $\$ 1.3$ billion.

5 Office of the Inspector General, the US Agency for International Development, Audit of USAID/Egypt's Democracy and Governance Activities, Audit Report No. 6-263-10-001-P, 27 October 2009, www.usaid.gov/oig/public/ fy10rpts/6-263-10-001-p.pdf

6 In this regard, see Shadi Hamid, Civil Society in the Arab World and the Dilemma of Funding, www.brookings.edu/articles/2010/10_middle east_hamid.aspx

7 Money, Market Access, Mobility - Three Ms to Underpin EU Support to its Southern Neighbours, 11 March 2011, www.enpi-info.eu/ mainmed.php?id_type $=1 \& i d=24485$

8 European Peace Building Liaison Office, 'Using More for More: Incentivizing Peace in

\section{References}

Ashton, C. (2011) 'Remarks at the Senior Officials' Meeting on Egypt and Tunisia', Speech/1 1/122, Brussels

Dworkin, A., Korski, D. and Witney, N. (2011) 'Egypt's Hybrid Revolution: A Bolder EU Approach', European Council for Foreign Relations Policy Briefing 32

Grant, C. (2011) A New Neighborhood Policy of the $E U$, London: Center for European Reform

Holm, U.; Malmvig, H. and Tassinariet, F. (2011) 'Growing Jasmines: What Should the EU do in Tunisia Now?', DIIS Policy Brief

Kausch, K. (2010) Assessing Democracy Assistance, Egypt: FRIDE

McInerney, S. (2011) 'The Logics of the American Donors to Promoting Democracy in the Middle East', in Democratic Change in the EU's Neighbourhood Policy', public statement, 25 July 2011.

9 European Commission, Joint Communication to the European Council, the European Parliament, the European Economic and Social Committee and the Committee of the Regions, Brussels, 8 March 2011, http://eeas.europa.eu/euromed/docs/ com2011_200_en.pdf

10 S. Füle, European Commissioner for Enlargement and Neighbourhood Policy, speech on the recent events in North Africa Committee on Foreign Affairs (AFET), European Parliament Brussels, 28 February 2011, http://europa.eu/rapid/pressReleasesAction. do? reference $=$ SPEECH $/ 11 / 130$

11 S. McInerney, SCAF's Assault on Egypt's Civil Society, 28 September 2011, http://mideast.foreignpolicy.com/category/ topic/foreign_aid

12 UNDP, Strategy of Response to Transformative Change Championed by Youth in the Arab Region.

13 ILO, Challenges in the Arab World: An ILO Response, www.ilo.org/public/english/bureau/pardev/ development/mena.htm (accessed 8 July 2011).

14 Press Conference by United Nations High Commissioner for Human Rights, Navi Pillay, Geneva, 30 June 2011 - Statement, www.ohchr.org/en/NewsEvents/Pages/Display News.aspx? NewsID $=11194 \&$ LangID $=\mathrm{E}$

15 Arab Transition Fund is an initiative to work through local or regional non-governmental entities which re-grant the funds to other local actors.

the Arab Region: State Policy and the Dynamics of Givil Society, Discussion Seminar, 2-3 April 2011, Brussels, Euro-Mediterranean Foundation of Support for Human Rights Defenders, PP 80-90, www.scribd.com/doc/ 59127297/Seminar-English-Report (accessed 4 November 2011)

Scarpetta,V. and Swidlicki, P. (2011) The EU and the Mediterranean: Good Neighbours?, Open Europe, www.openeurope.org.uk/research/ enp2011.pdf (accessed 12 September 2011)

Schafer, I. (2011) Revolutions among the Southern Neighbors - Time for a New EU Policy towards the Arab World, Berlin: Heinrich Böll Stiftung

Sharp, J.M. (2011) Egypt in Transition, Washington DC: Congressional Research Service

Soros, G. (2011) 'Why Obama has to get Egypt Right', Washington Post, 3 February, 
www.washingtonpost.com/wp-dyn/content/ article/2011/02/02/AR2011020205041_pf.html (accessed 12 September 2011)

Trofimov, Y. (2011) 'Egypt Opposes US's

Democracy Funding', Wall Street Journal, 14 June,
http://online.wsj.com/article/SB 1000142 4052702304665904576383123301579668.html (accessed 12 September 2011) 